Annals of International Medical and Dental Research

E-ISSN: 2395-2822 | P-ISSN: 2395-2814

Vol-8, Issue-1 | January-February 2022

DOI: 10.53339/aimdr.2022.8.1.47

Page no- 379-384 | Section- Research Article (Forensic Medicine)

\title{
A Forensic Autopsy Study of Dead Foetuses and Newborns
}

\author{
Jatinder Pal Singh ${ }^{1}$, Kuldip Kumar ${ }^{2}$, Sunny Basra ${ }^{3}$, Jaspinder Pratap Singh ${ }^{{ }^{*}}$
}

\begin{abstract}
${ }^{1}$ Assistant Professor, Department of Forensic Medicine, Government Medicial College, Amritsar, Punjab, India.

Email: drjpee@yahoo.com

Orcid ID: 0000-0002-6501-2286

${ }^{2}$ Associate Professor, Department of Forensic Medicine, Government Medicial College, Amritsar, Punjab, India.

Email: kuldipgmc@yahoo.com

Orcid ID: 0000-0002-2176-5040

3Junior Resident, Department of Forensic Medicine, Government Medicial College, Amritsar, Punjab, India.

Email: sunny.basra33@gmail.com

Orcid ID: 0000-0001-5116-5970

4Senior Resident, Department of Forensic Medicine, Government Medicial College, Amritsar, Punjab, India.

Email: jaspinderpsingh@gmail.com

Orcid ID: 0000-0003-3510-4400

*Corresponding author
\end{abstract}

Received: 25 August 2021

Revised: 21 November 2021

Accepted: 02 December 2021

Published: 22 December 2021

\begin{abstract}
Background: The term abandonment refers to babies or foetuses which are found abandoned at various unwanted places such as gutter, rubbish dumps, railway tracts and bushes. It does not refer to live born babies left in places, such as hospitals where care can be given by someone other than the mother. Aims and Objectives: To find out the distribution of death cases of newborns/feotuses and to trace its probable reason and its relationship with female foeticide. Methods: A retrospective study of all the medico-legal autopsies of foetuses and newborns was conducted in Forensic medicine and Toxicology department, Government Medical College, Amritsar (Punjab) from Jan 1, 2014 to Jul 31, 2021. During this period, 46 cases of fetal and newborn deaths had been studied. Results: The dead bodies of known foetuses/newborns is $43.5 \%$ cases while total unknown cases were $56.5 \%$ cases. $32.6 \%$ cases were non viable foetuses while $10.8 \%$ cases died as a result of prematurity. All the unknown cases $(56.5 \%)$ were found from the abandoned places like street, bushes, canal side, water bodies that mainly includes pond and railway tract. Conclusion: Despite, the problem is present in every corner of the nation, there is dearth of research studies on this issue. Stringent measures and strict checks are required against antenatal sex determination. The motive behind the abandonment of foetuses can be any, but this grave issue needs urgent attention.
\end{abstract}

Keywords:- Foeticide, Newborns, Abandonment, Viability, Concealment of Birth.

\section{INTRODUCTION}

The abandonment of the newborn/foetus is an important, but often neglected issue. There have been news reports of abandoned foetuses from different parts of India.[1] The term abandonment refers to babies or foetuses which are found abandoned at various unwanted places such as gutter, rubbish dumps, railway tracts and bushes. It does not refer to live born babies left in places, such as hospitals where care can be given by someone other than the mother.[2]

According to The Indian Penal Code, foeticide and intentional abandonment of a child are considered punishable under Sections 315 IPC and 317 IPC. The Pre-Conception and PreNatal Diagnostic Techniques (prohibition of sex selection) Act of 1994 is federal legislation that was enacted by the Indian Parliament to stop female foeticides and to arrest the 
Annals of International Medical and Dental Research

E-ISSN: 2395-2822 | P-ISSN: 2395-2814

Vol-8, Issue-1 | January-February 2022

DOI: $10.53339 /$ aimdr.2022.8.1.47

Page no- 379-384 | Section- Research Article (Forensic Medicine)

declining sex ratio in the country. The Act has banned prenatal sex determination, using various diagnostic techniques, yet it has failed to curb the problem of sex selective abortions completely.[3,4]

As the result of abandonment, many infanticides and neonaticides takes place where the alleged mother leaves the infant or newborn in an abandoned place without protection or shelter, intending to kill the child. Such dead fetuses or newborns are then found abandoned in places.[5]

\section{Aims and Objectives}

To find out the distribution of death cases of newborns/feotuses and to trace its probable reason and its relationship with female foeticide.

\section{MATERIAL AND METHODS}

A retrospective study of all the medico-legal autopsies of foetuses and newborns was conducted in the Forensic Medicine and Toxicology Department, Government Medical College, Amritsar (Punjab) from Jan 1, 2014 to Jul 31, 2021. During this period, 46 cases of fetal and newborn deaths were reported in the department. All the data related to medicolegal autopsy of newborn was analyzed for identity, gender, viability at birth, cause of deaths in liveborn, and location of recovery of the bodies. The details of these cases were inferred, in a standard performa, from the post mortem records and the inquest papers of the investigating officer. No permission from institutional ethical committee was taken as data was collected from the old records of the department.

\section{RESULTS}

In the present study, in a total of 46 cases of dead fetuses/ newborns, female preponderance (59\% cases) of dead foetuses and newborns is more as compared to males (39\% cases). [Figure 1] The Male is to Female ratio is $2: 3$. The gender of the deceased fetus/ newborn could not be ascertained and DNA examination for gender was sent in $2 \%$ of cases.

[Table 1] shows that the dead bodies of known fetus/newborns are 20 cases(43.5\%) while total unknown cases were 26 cases (56.5\%). Among the known cases, $28.3 \%$ were males while $15.2 \%$ cases were females and in the unknown fetuses/newborns, the number of females(39.13\% cases) was much higher as compared to the unknown males( $17.4 \%$ cases).

[Table 2] shows the cause of death in the bodies brought for post mortem examination. The majority of cases(34.9\%) died, were as a result of injuries which includes head injuries, chest injuries and injuries over the face; this mainly constitutes the killing of newborns i.e infanticide or foeticide cases. 32.6\% cases were non-viable foetuses, while $19.6 \%$ of cases were dead born and $10.8 \%$ of cases died as a result of prematurity. Out of all the cases, $2.1 \%$ cases were still born babies.

[Table 3] shows that all the unknown cases (56.5\%) were found from the abandoned places like streets, bushes, canal side, water bodies that mainly includes pond and railway tract while among the known cases that are $41.3 \%$ total cases were hospital deaths which include 
Annals of International Medical and Dental Research

E-ISSN: 2395-2822 | P-ISSN: 2395-2814

Vol-8, Issue-1 | January-February 2022

DOI: $10.53339 /$ aimdr.2022.8.1.47

Page no- 379-384 | Section- Research Article (Forensic Medicine)

the cases of negligence, death due to sepsis and also the unknown live infants brought to the hospital for treatment. $2.2 \%$ of cases were deaths at home which were as a result of assault as reported in the inquest papers.

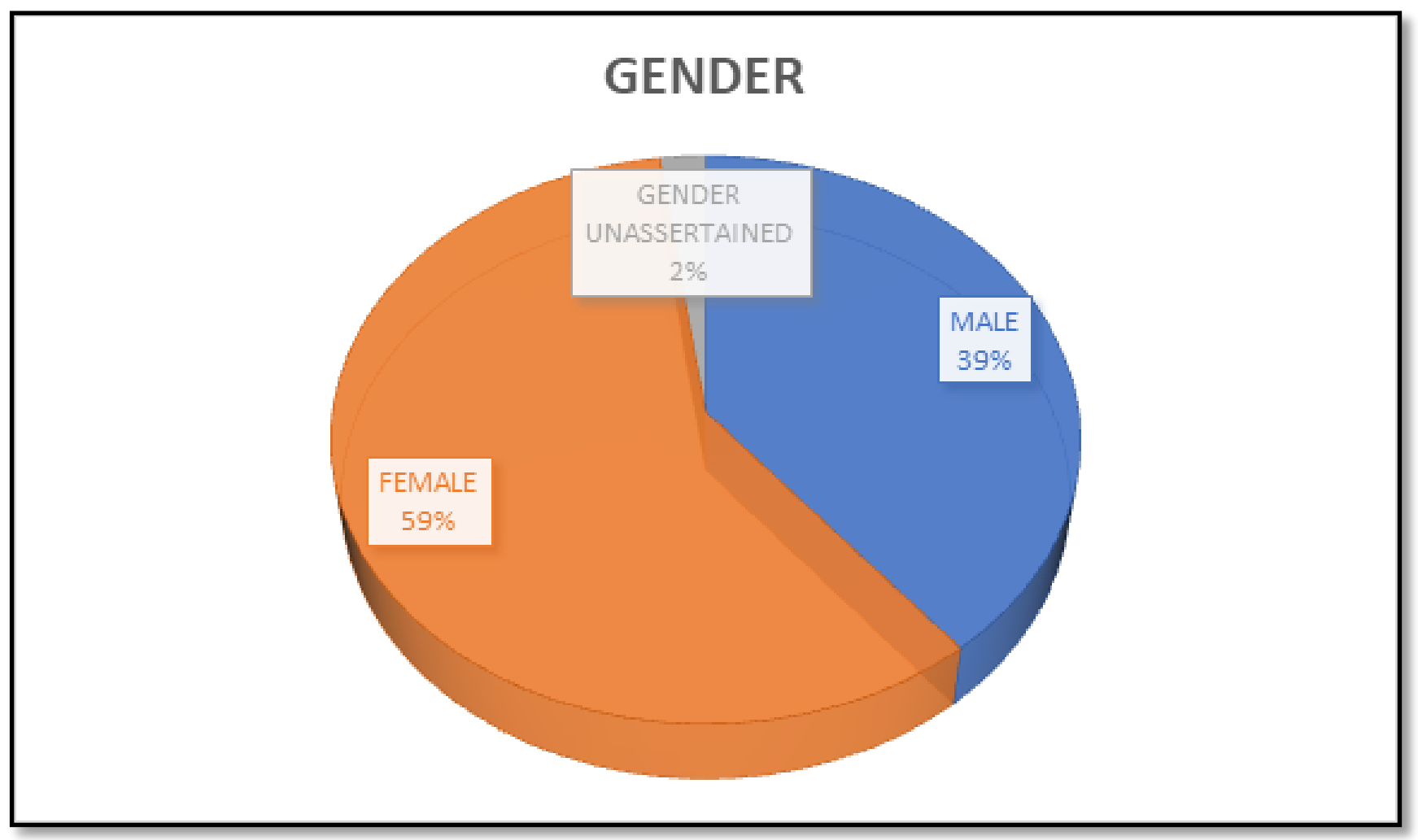

Figure 1: Distribution According to the Gender of the Fetus/Newborn

Table 1: Distribution on the Basis of Known/Unknown

\begin{tabular}{|l|l|l|l|}
\hline & Male & Female & Total \\
\hline Known & $13(28.3 \%)$ & $07(15.2 \%)$ & $20(43.5 \%)$ \\
\hline Unknown & $08(17.4 \%)$ & $18(39.13 \%)$ & $26(56.5 \%)$ \\
\hline Total & $21(45.7 \%)$ & $25(54.3 \%)$ & $46(100 \%)$ \\
\hline
\end{tabular}

Table 2: Cause of Death in Foetuses/Newborns

\begin{tabular}{|l|l|l|}
\hline Cause of death & Number & Percentage \\
\hline Injuries & 16 & $34.9 \%$ \\
\hline Non-viability & 15 & $32.6 \%$ \\
\hline Dead born & 09 & $19.6 \%$ \\
\hline Prematurity & 05 & $10.8 \%$ \\
\hline Still born & 01 & $2.1 \%$ \\
\hline
\end{tabular}


Annals of International Medical and Dental Research

E-ISSN: 2395-2822 | P-ISSN: 2395-2814

Vol-8, Issue-1 | January-February 2022

DOI: 10.53339/aimdr.2022.8.1.47

Page no- 379-384 | Section- Research Article (Forensic Medicine)

\begin{tabular}{|c|c|c|}
\hline Total & 46 & 100 \\
\hline \multicolumn{3}{|c|}{ Table 3: Distribution of Place of Finding of Body of Foetuses/Newborns } \\
\hline Place where found & \begin{tabular}{l|l} 
& Number
\end{tabular} & Percentage \\
\hline Hospital death & 19 & 41.2 \\
\hline Street & 08 & 17.4 \\
\hline Bushes & 08 & 17.4 \\
\hline Canal side & 05 & 10.8 \\
\hline Water body & 03 & 6.6 \\
\hline Railway track & 02 & 4.4 \\
\hline Home deaths & 01 & 2.2 \\
\hline Total & 46 & 100 \\
\hline
\end{tabular}

\section{DISCUSSION}

In the present study, female preponderance (59\% cases) of dead fetuses and newborns is more as compared to males (39\% cases) which is consistent with findings A. Krishnajaneyulu et al.[6] (2021) where female to male ratio is 3:2. In this study, the majority of unknown foetuses bodies are females found in state of advanced putrefaction. The observations in the present study are also similar to the study conducted by C Behera et al.[7] (2016) where a nearly equal number of males( $48 \%$ cases) and female $(46 \%$ cases) dead bodies of feotuses/newborns were brought for postmortem examination while in $8 \%$ cases gender was unascertained. However, in another study conducted in North Carolina, United States by Herman-Giddens et al.[8] (2003) where a total of $58.8 \%$ were males and $35.3 \%$ were females and $5.9 \%$ of indeterminate due to advanced stage of decomposition. In another study conducted in Pretoria in South Africa by du Toit-Prinsloo L et al.[9] (2016) which also showed results different as compared to the present study in which dead body of male foetuses was predominant (49\%) as compared to females (32\%) while in $19 \%$ cases, the gender was unascertained. The main reason for low sex ratios and missing girl child in India and China is strong preferences for son is prevalent.10] In a report from South Delhi highlighted the sudden increase in the number of sex selective abortions after antenatal sex determination became freely available in India.[11] Another report also confirmed the high prevalence of female foeticide in Asian countries like India and China.112] According to Bonnet(1993),[13] which highlights about the newborns were abandoned and left to die. Perhaps reason might be the bias attitude towards males present in the society adds to the increase in number of abandoned female foetuses/ newborns.

The findings in this present study are consistent with study of C Behera et al. (2016),[?] where majority of dead foetuses/newborns were nonviable (36\% cases). In foetuses/ newborns that died due to injuries which account for $34.9 \%$ cases in the present study, the findings are consistent with findings of C Behera et al. (2016), [7] where head injury due to blunt forces was the most common cause of death due to injuries. Abandoned foetuses are majorly found in the 
Annals of International Medical and Dental Research

E-ISSN: 2395-2822 | P-ISSN: 2395-2814

Vol-8, Issue-1 | January-February 2022

DOI: $10.53339 /$ aimdr.2022.8.1.47

Page no- 379-384 | Section- Research Article (Forensic Medicine)

varying stages of putrefaction, along with being subjected to post mortem trauma or predation, making interpretation of trauma difficult. In another study conducted at Pretoria in South Africa by du Toit-Prinsloo L et al. (2016)9 findings are consistent with the findings of the present study where the majority of dead bodies of foetuses/newborns (57\% cases) brought for post mortem examination.

The majority of the unknown cases in the present study have been found at abandoned places that include streets $(17.4 \%)$, bushes (17.4\%), Canal side (10.8\%), water bodies(6.6\%) and railway tract $(4.4 \%)$, these findings are consistent with findings of study conducted at Guntur by A. Krishnajaneyulu et al. (2021), [6] where majority of infants $(56 \%$ cases) were abandoned by the parents at hospital probably as child was dead and $44 \%$ cases the birth was concealed illegally by disposing off the baby at various abandonded places like drainage canals, dustbins, railway premises and bushes. Such babies probably could be unwanted ones, born to unmarried women, delivered as stillborn or dead born or criminally aborted. Similar findings were found in the study conducted in north Tunisia by Ben Khelil $\mathrm{M}$ et al (2019), [14] where the majority of dead bodies of foetuses/newborns were found by the public roads in $40.9 \%$ cases. The findings in the present study are also consistent with those of Herman-Giddens et al. (2003), [] w where majority of dead bodies of foetuses/newborns was found in trash $(23.5 \%)$, landfills, woods or roadside(23.6\%). In a another study conducted by Gheorghe et al. (2011),[15] in Denmark discussed 11 cases of abandonment of babies from year 1997 - 2008, where the most common means of disposal was in a plastic bag $(60 \%)$; indicating concealment of birth and abandonment of babies.

\section{Limitations of study}

This study provides an opportunity to understand the epidemiology of cases of active and passive killing of new born by their parents. We can safely assume that our study of foetuses/newborn dead bodies is an underestimate as very less amount of similar studies has been conducted in India. Despite, the problem is present in every corner of the nation, there is dearth of research studies on this issue. A prevention is one of the mandatory focus, but the current evidence based on prevention is limited.

\section{CONCLUSIONS}

Stringent measures and strict checks are required against antenatal sex determination. Before any criminal charge can be anticipated, clear investigation into number of issues is required for the discovery of discarded remains of foetus or infants. Facilities like special orphanages, and anonymously accepting the newborns of unwanted pregnancies, may help to minimise the problem of abandoned foetuses. Education of young females regarding family planning methods and improving their moral thinking which can avoid unwanted pregnancies thus reducing abandonment of foetuses \& concealed birth cases. The motive behind the abandonment of foetuses can be any, but this grave issue needs urgent attention. 
Annals of International Medical and Dental Research

E-ISSN: 2395-2822 | P-ISSN: 2395-2814

Vol-8, Issue-1 | January-February 2022

DOI: 10.53339/aimdr.2022.8.1.47

Page no- 379-384 | Section- Research Article (Forensic Medicine)

\section{REFERENCES}

1. Thomson A. Why are potential women being killed? Midwifery. 1993;9(4):181-2. doi: 10.1016/0266-6138(93)90001-9.

2. Porter T, Gavin H. Infanticide and neonaticide: a review of 40 years of research literature on incidence and causes. Trauma Violence Abuse. 2010;11(3):99-112. doi: 10.1177/1524838010371950.

3. Madan K, Breuning MH. Impact of prenatal technologies on the sex ratio in India: an overview. Genet Med. 2014;16(6):425-432. doi:10.1038/gim.2013.172

4. Das Gupta M. Is banning sex-selection the best approach for reducing prenatal discrimination? Asian Popul Stud. 2019;15(3):319-336. doi:10.1080/17441730.2019.1671015

5. Abrahams N, Mathews S, Martin LJ, Lombard C, Nannan N, Jewkes R. Gender Differences in Homicide of Neonates, Infants, and Children under $5 \mathrm{y}$ in South Africa: Results from the CrossSectional 2009 National Child Homicide Study. PLoS Med. 2016;13(4):e1002003. doi: 10.1371/journal.pmed.1002003.

6. Krishnajaneyulu A, Devchand N, Uppu RS, Reddy TT. A Medico Legal Study of Fetal Deaths in and Around Guntur. Indian J Forensic Med Toxicol. 2021;15(3):16-22.

7. Behera C, Sikary AK, Krishna K, Garg A, Chopra S, Gupta SK. Medico-legal autopsy of abandoned foetuses and newborns in India. Med Leg J. 2016;84(2):109-11. doi: 10.1177/0025817216631456.

8. Herman-Giddens ME, Smith JB, Mittal M, Carlson M, Butts JD. Newborns killed or left to die by a parent: a population-based study. JAMA. 2003;289(11):1425-9. doi: 10.1001/jama.289.11.1425.

9. du Toit-Prinsloo L, Pickles C, Smith Z, Jordaan J, Saayman G. The medico-legal investigation of abandoned fetuses and newborns--a review of cases admitted to the Pretoria Medico-Legal Laboratory, South Africa. Int J Legal Med. 2016;130(2):569-74. doi: 10.1007/s00414-015-1198-y.

10. Jha $P$, Kumar R, Vasa $P$, Dhingra N, Thiruchelvam D, Moineddin R. Low male-to-female sex ratio of children born in India: national survey of 1.1 million households. The Lancet. 2006;367(9506):2118.doi: 10.1016/ S0140-6736(06)67930-0

11. Sahni M, Verma N, Narula D, Varghese RM, Sreenivas V, Puliyel JM. Missing girls in India: infanticide, feticide and made-to-order pregnancies? Insights from hospital-based sex-ratioat-birth over the last century. PLoS One. 2008;3(5):e2224. doi:10.1371/journal.pone.0002224

12. Hesketh T, Lu L, Xing ZW. The consequences of son preference and sex-selective abortion in China and other Asian countries. CMAJ. 2011;183(12):13741377. doi:10.1503/cmaj.101368

13. Bonnet C. Adoption at birth: prevention against abandonment or neonaticide. Child Abuse Negl. 1993;17(4):501-13. doi: 10.1016/0145-2134(93)90025$\mathrm{z}$.

14. Ben Khelil M, Farhani F, Harzallah H, Allouche M, Gharbaoui M, Banasr A, et al. Patterns of homicide in North Tunisia: a 10-year study (2005-2014). Inj Prev. 2018;24(1):73-77. doi: 10.1136/injuryprev2016-042123.

15. Gheorghe A, Banner J, Hansen SH, Stolborg U, Lynnerup N. Abandonment of newborn infants: a Danish forensic medical survey 1997-2008. Forensic Sci Med Pathol. 2011;7(4):317-21. doi: 10.1007/s12024-011-9253-6.

Source of Support: Nil, Conflict of Interest: None declared 